\title{
Involvement of Bone in Systemic Endocrine Regulation
}

\author{
I. ZOFKOVA ${ }^{1}$ \\ ${ }^{1}$ Institute of Endocrinology, Prague, Czech Republic
}

Received December 19, 2017

Accepted March 22, 2018

On-line July 25, 2018

\section{Summary}

The skeleton shows an unconventional role in the physiology and pathophysiology of the human organism, not only as the target tissue for a number of systemic hormones, but also as endocrine tissue modulating some skeletal and extraskeletal systems. From this point of view, the principal cells in the skeleton are osteocytes. These cells primarily work as mechano-sensors and modulate bone remodeling. Mechanically unloaded osteocytes synthetize sclerostin, the strong inhibitor of bone formation and RANKL, the strong activator of bone resorption. Osteocytes also express hormonally active vitamin $\mathrm{D} \quad\left(1,25(\mathrm{OH})_{2} \mathrm{D}\right)$ and phosphatonins, such as FGF23. Both $1,25(\mathrm{OH})_{2} \mathrm{D}$ and FGF23 have been identified as powerful regulators of the phosphate metabolism, including in chronic kidney disease. Further endocrine cells of the skeleton involved in bone remodeling are osteoblasts. While FGF23 targets the kidney and parathyroid glands to control metabolism of vitamin D and phosphates, osteoblasts express osteocalcin, which through GPRC6A receptors modulates beta cells of the pancreatic islets, muscle, adipose tissue, brain and testes. This article reviews some knowledge concerning the interaction between the bone hormonal network and phosphate or energy homeostasis and/or male reproduction.

\section{Key words}

Osteocytes • Sclerostin • Phosphatonins • FGF23 - Klotho a • Phosphate homeostasis $\bullet 1,25(\mathrm{OH})_{2}$ vitamin D • Chronic kidney disease • Osteoblasts • Osteocalcin • Insulin secretion • Insulin tissue sensitivity • Testosterone expression • Male reproduction

\section{Corresponding author}

I. Zofkova, Institute of Endocrinology, Narodni 8, 11694 Prague 1, Czech Republic. E-mail: izofkova@upcmail.cz

\section{Introduction}

Bone is traditionally understood not only as a mechanical frame, but also as the tissue targeting a number of hormones, such as $1,25(\mathrm{OH})_{2}$ vitamin $\mathrm{D}$, calcitonin, sexual steroids, glucocorticoids and thyroid hormones (Dumic-Cule et al. 2014). Recently, the skeleton has been shown to be an endocrine organ producing molecules, which via autocrine/paracrine level modulate bone homeostasis, but significantly also some extraskeletal systems.

Bone remodeling is derived from the close interaction between osteoblasts (cells of mesenchymal origin) stimulating bone formation and osteoclasts (cells of monocyte-macrophage lineage) activating bone resorption. A number of osteoblastic cytokines interfere with RANK and in this way inhibit osteoclastogenesis and bone resorption, respectively (reviewed by Kitamura et al. 2013). Maturation of osteoblasts is promoted by the canonical Wnt (wingless proteins) pathway, as well as by the hormones synthesized in the osteocytes, such as $1,25(\mathrm{OH})_{2} \mathrm{D}_{3}$ (Turner et al. 2014) and/or growth factors, e.g. BMP-4 (activated by the p38 MAP kinase) (Kondo et al. 2014). Autoregulation processes, such as acceleration of osteoclastic apoptosis together with the activation of osteoblastic differentiation, start when bone resorption is activated in a way that it prevails over the bone formation. At this moment, the metabolic equilibrium of the healthy skeleton resets to the physiological level (Nakahama 2010). 


\section{The role of osteocytes in bone homeostasis}

In the adult skeleton, osteocytes are without doubt the most abundant multifunctional cells of the bone matrix, interconnecting with each other and with other cells, such as osteoblast, lining cells and stromal cells via the cell network. Osteocytes are long-lived cells, which occupy the lacunae, contained in calcified matrix of the skeleton. They are involved in bone remodeling transmitting signals to other osteocytes in response to deformation of bone. These cells are derived from osteoblasts and occupies small channels canaliculi. Osteocytes are fundamental sensors of mechanical loading, which trigger anabolic mechanisms in the skeleton. The cells are activated depending on the intensity and the duration of the strain. The mechanical impulse is transmitted through the canalicular system into the cytoplasm and after humoral signalizations through the second messengers, such as nitric oxide, prostaglandin $\mathrm{E}$ and/or Wnt/ $\beta$-catenin signaling positively modulates bone formation (Turner et al. 2009, DelgadoCalle and Bellido 2015, Neve et al. 2012, Dallas et al. 2013, Capulli et al. 2014, Spatz et al. 2015, Nakahama 2010, Sapir-Koren and Livshits 2014). Repp et al. (2017) observed decrease in canalicular density and quantity within osteons of the aging human skeleton due to micropetrosis. The authors outlined the hypothesis, that this phenomenon inhibits the mechano-sensitivity of the skeleton in elderly subjects. Mechanically unloaded osteocytes synthetize sclerostin, the strong inhibitor of bone formation and RANKL, the strong activator of bone resorption. Sclerostin is antagonist of Wnt/ $\beta$-catenin pathway, working as a negative local/paracrine regulator of bone formation. An interesting preliminary report from an experimental study on porcine explants (which is prepared to be published in Bone by Curtis et al. 2017) suggests that mechanical stimulation and a subsequent increase in trabecular bone formation could also be transduced in bone marrow, independently from osteocyte signaling. Therefore, the influence of mechanical stress on bone metabolism appears to be more complex.

The favorable effect of mechanical loading on the skeleton and the detrimental influence of unloading are documented by a number of experimental and clinical studies.

Sclerostin plays a crucial role in the regulation of the mechano-sensitivity of the skeleton. The molecule is expressed by osteocytes. Experimental studies have shown, that mechanical unloading of osteocytic cell line (Ocy454) stimulates sclerostin production and, via an increase in RANKL/OPG ratio activates bone resorption (Spatz et al. 2015). Furthermore, sclerostin is the osteocytic antagonist of $\mathrm{Wnt} / \beta$-catenin pathway, working as a negative local/paracrine regulator of bone formation) (Drake and Khosla 2017). Sclerostin deficiency in humans and animals could be induced by long-term treatment with sclerostin antibodies (Appelman-Dijkstra and Papapoulos 2016, McClung 2017).

A gradual physiological increase in circulating sclerostin has been observed in the course of the menopausal transition to early postmenopause, which is associated with the relative decrease in bone formation compared to actual bone resorption (Matsui et al. 2016). In this respect, sclerostin appears to be an effective marker for monitoring the dynamics of bone homeostasis during the early menopause. Kalem et al. (2017) and some others (Mödder et al. 2011) reported a negative association between blood sclerostin levels and BMD in postmenopausal women. Studies in humans and animals have demonstrated the suppressive effects of estrogen on circulating sclerostin (reviewed by Drake and Khosla 2017). Thus estrogen appears to be an effective physiological inhibitor of sclerostin and supports the role of high sclerostin levels in the development of postmenopausal osteoporosis.

Alarming data were obtained from healthy male athletes, where higher sclerostin levels were found after long-term physical training, not related to other bone turnover markers and PTH (Zagrodna et al. 2016). Moreover, higher sclerostin levels were also observed in subjects with prediabetes, where sclerostin levels correlated with insulin sensitivity. On the other hand, carboxylated osteocalcin correlated with insulin resistance in obese postmenopausal women. Nevertheless, recently was observed, that osteocalcin signaling in myofibers is needed for optimal adaptation to exercise (Mera 2016).

In uremic patients with low metabolic turnover, an exaggerated expression of sclerostin is found. Sclerostin levels in circulation increased in the pre-hemodialysis period and declined in post hemodialysis. Sclerostin correlated with parameters of dialysis adequacy, such a creatinine levels and could represent a defensive mechanism, leading to improvement of vascular disease and bone homeostasis (Bruzzese et al. 2016). From this point of view, sclerostin 
antagonists possess a potential role in the treatment of renal osteodystrophy.

Further molecules expressed by osteocytes are phosphatonins, such as FGF23, sFRP-4 and MEPE, which have been mostly identified as powerful regulators of phosphate metabolism (Cavalli et al. 2012, Chapurlat and Confavreux 2016, Mace et al. 2017). The well recognized phosphatonin FGF23 (fibroblast growth factor 23 ) is a powerful phosphaturic hormone, which reduces renal transport of phosphates.

The expression of FGF23 is under the control of phosphate, sclerostin and $1,25(\mathrm{OH})_{2} \mathrm{D}$ (Cavalli et al. 2012, Sapir-Koren and Livshits 2014) and PTH (Rhee et al. 2011). While ablation of PTH1R reduced serum FGF23 protein levels by $50 \%$, intermittent hPTH(1-34) injection markedly increased FGF23 mRNA and serum intact FGF23 levels (Fan et al. 2016).

Inactive molecule of vitamin D (25OHD) synthesized in the liver, represents a precursor for dihydroxylated metabolites, including biologically active $1,25(\mathrm{OH})_{2} \mathrm{D}_{3}$ targeting the intestine, bone and other tissues. The kidney is generally considered to be the major site of synthesis of $1,25(\mathrm{OH})_{2} \mathrm{D}_{3}$, although this metabolite can also be expressed in extrarenal tissues. There is a feedback between FGF23 gene transcription and vitamin $\mathrm{D}$. While $1,25(\mathrm{OH})_{2} \mathrm{D}_{3}$ positively modulates FGF23 synthesis (Cavalli et al. 2012), FGF23 inhibits $1 \alpha$-hydroxylase and activate 24-hydroxylase, both of which lead to decrease in circulating $1,25(\mathrm{OH})_{2} \mathrm{D}$ with subsequent inhibition of bone formation and bone mineralization (Sapir-Koren and Livshits 2014, Rolvien et al. 2017). Moreover, osteocytes, similarly to the soft tissues (of the intestine and kidney) express specific enzyme transforming the inactive precursor $25(\mathrm{OH}) \mathrm{D}$ to $1,25(\mathrm{OH})_{2} \mathrm{D}_{3}$, which targets osteoblasts at the paracrine level and promotes bone formation (Rolvien et al. 2017).

The elementary co-receptor of FGF23 is transmembrane protein Klotho (251 aminoacids). It is expressed in the parathyroid glands, kidneys and in low amount in osteoblasts and/or osteocytes. It enables interaction between FGF23 and its receptors. Klotho $\alpha$ alone has been identified as an effective anti-aging factor, the synthesis of which declines with age (Kurosu and Kuro-O 2009). A Klotho-deficient status is associated with premature aging, which is manifested by endothelial dysfunction and accelerated calcinosis of vessels (Kuro et al. 2017, Vervloet et al. 2014, Olauson et al. 2014).

Apart from the bone, parathyroid gland, cardiovascular and central nervous systems, major functions of FGF23 - Klotho system have been discovered in relation to the kidney function. High activity of the FGF23 - Klotho complex signalizes renal injury together with the risk of vascular disease. In mice with renal failure FGF23 treated bone required Klotho to increase FGF23 mRNA (Kaludrejovic et al. 2017). Thus, the anti-aging factor Klotho is crucial for FGF23 production in renal failure.

Increased FGF23 levels are measured during the chronic kidney disease (CKD), when they correlate independently with bone markers (ALP and N-terminal telopeptide levels) and with vertebral fracture occurrence (Quarles 2012, Kanda et al. 2012). Serum FGF23 fluctuates in relation to renal function and serum PTH and offers diagnostic utilization in CKD (Rhee et al. 2011, Fan et al. 2016). In the early stage of CKD, FGF23 inhibits renal tubular phosphate reabsorption and reduces serum $1,25(\mathrm{OH})_{2} \mathrm{D}_{3}$ via activation of Cyp24 (Quarles, 2012). Thus, at this moment, the FGF23 - Klotho system works as an adaptive mechanism, which protects the organism against the retention of phosphate and brakes overproduction of PTH, a vascular toxin, which accelerates arterial stiffness and coronary calcification in these patients. During the progression of renal disease, FGF23 continuously increases due to a decrease in renal excretion (reviewed by Mace et al. 2017). In the advanced stages of CKD, an extensive increase in PTH level further stimulates synthesis of FGF23, which otherwise partly compensates for phosphate retention, but simultaneously induces cardiovascular complications. Overall, serum FGF23 is an effective protective factor against toxic phosphate retention and promising putative marker of cardiovascular risk in the early phase of CKD. Later in CKD, FGF23 expression progressively amplifies (while Klotho declines). Subsequent hyperphosphatemia further accelerates vascular calcification and the risk of cardiovascular mortality in the late phase of CKD markedly increases. Anticalcific ability could be in part restored by the activation of the vitamin $\mathrm{D}$ receptor (Quarles 2012).

In addition to systemic circulation, FGF23 is present in the cerebrovascular fluid. In the course of CKD, the FGF23 is taken up in the hippocampus, where it alters the neuronal morphology and causes memory insufficiency (Hensel et al. 2016). Interestingly, FGF23 and Klotho $\alpha$ have also been found increased in cirrhotic alcoholics. Quintero-Platt et al. (2017) hypothesize that FGF23 - Klotho system have some pathophysiological role in cardiovascular disease complicating hypertension, 
diabetes, left ventricular hypertrophy and obesity.

Mutations in FGF23 and/or Klotho genes lead to hypervitaminosis $\mathrm{D}$, hyperphosphatemia, hyperostosis and ectopic calcifications. Similarly, disruption of the FGF23 - Klotho axis increases phosphate retention and the syndrome of mammal aging (Kuro 2016). On the other hand, extremely high activity of FGF23 manifests as hereditary or acquired hypophosphatemic rickets (Cavalli et al. 2012, Quarles 2012).

Finally, FGF23 is an endocrine factor regulating a broad spectrum of systems (Erben 2016; reviewed by Zofkova 2015). After modulation by Klotho, a key role of FGF23 is the regulation of phosphate metabolism in patients with damaged kidneys.

\section{Osteoblasts}

Osteoblasts are cells of mesenchymal origin stimulating bone formation in the process of bone remodeling. The key role here is played by the Wnt- $\beta$-catenin pathway, which is antagonized by sclerostin at the local/paracrine level (Drake and Khosla 2017). Besides the Wnt- $\beta$-catenin molecule, osteoblasts carry out osteocalcin (reviewed by Chapurlat and Confavreux 2016, Cappariello et al. 2016). Expression of the later peptide is under the negative control of the Esp gene, however its bioactivity is also modulated by insulin, leptin, glucocorticoids and the sympathetic nervous system. Osteocalcin is gamma-carboxylated to three glutamic residues, requiring vitamin $\mathrm{K}$ reduction by VKORC1 reductase (Ferron et al. 2015). In addition to bone formation, osteocalcin appears to play some role in bone matrix mineralization (partly mediated by IGF signaling) (Zhang et al. 2002). However, recent studies show a broader spectrum of osteocalcin activities working through the specific G-protein coupled receptors GPRC6A. Undercarboxylated (un-osteocalcin) is hormonally active molecule, modulating metabolism of phosphates, $1,25(\mathrm{OH})_{2} \mathrm{D}$ vitamin and some extraskeletal systems, such as male reproduction, cognition and primarily the glucose metabolism (Cappariello et al. 2016). Therefore, ablation of GPRC6A (-/-) induces a scale of metabolic dysregulations (Zoch et al. 2016).

Thus, osteocalcin is a novel hormone, which via GPRC6A receptors controls metabolism of phosphate and $1,25(\mathrm{OH})_{2}$ vitamin $\mathrm{D}$, but also insulin secretion by pancreatic $\beta$-cells and fatty acid metabolism in the liver (Pi and Quarles 2013). Osteocalcin deficient mice showed hyperglycemia, which was normalized after osteocalcin supplementation (Zoch et al. 2016, Mizokami et al. 2014, Mizokami et al. 2017). In accordance with the experimental data, negative correlations between serum un-osteocalcin and glycemia, hemoglobin A1c (HbA1c) levels and the parameters of insulin resistance in peripheral tissues, including the muscles (where GPRC6A receptors are also present) have been found in normal women (Weiler et al. 2013). Muscle contraction is characterized by increased insulin sensitivity and in this tissue. Thus, it could be postulated, that increased GPRC6A expression in muscles during the physical training is the causal mechanism of increased insulin sensitivity in athletes (Levinger et al. 2016). Osteocalcin with its receptors represents a functional coupling between bone and energy metabolism. A negative association between un-carboxylated osteocalcin levels and adiposity has been observed in school children, which allows un-osteocalcin to predict the risk for adiposity in children (Boucher-Berry et al. 2012). Together, osteoblasts are understood as highly specialized endocrine cells targeting energy metabolism at different molecular levels (Anderson et al. 2012, Cappariello et al. 2016, Sato and Takeda 2016). The complexity of interaction between bone and energy metabolism also documents the fact, that adipocyte-derived leptin inhibits (via the central sympathetic nervous system) osteoblast activity and osteocalcin synthesis and slows down bone formation (Ferron and Lacombe 2014).

An interesting article published by Simon et al. (2017) reports new data about galectin-3. This molecule is a member of the $\beta$-galactoside-binding lectin family expressed in bone, which influences the interplay between osteoblasts-osteoclasts and the renewal of trabecular bone independently of the RANKL/OPG system.

\section{Bone and male reproduction}

Until now, the relationship between the skeleton and reproduction has been considered to be limited to the regulation of bone remodeling by sexual steroids. It is well known, that androgens and estrogens are responsible for sexual dimorphism in the development of peak bone mass and the adaptation of bone to mechanical loading. Androgen insufficiency due to an imbalance in the hypophyseal-gonadal axis and/or low activity of enzymes regulating sex steroid production together with disorders in thyroid function, oxidative stress, autoimmunity and life style, including zinc deficiency in the diet and genetic 
factors may lead to male infertility (Kumar et al. 2014, Stouffs et al. 2014).

Recently, male reproduction has also been shown to be under the control of the skeleton. Studies in osteocalcin $^{-/-}$or GPRC6A $\mathrm{A}^{-/-}$mice support the stimulating role of osteocalcin through GPRC6A receptors in regulation of circulating $\mathrm{LH}$. Furthermore, steroidogenic enzymes cytochromes $\mathrm{P} 450 \mathrm{scc}$ and $\mathrm{P} 450 \mathrm{c} 17$ required for synthesis and release of testosterone could be activated by osteocalcin through the GPRC6A receptor localized on Leydig cells (Karsenty and Oury 2014, Oury et al. 2013). However, there is no evidence that the LH-testosterone system modulates osteocalcin expression (Oury et al. 2013, reviewed by Karsenty and Oury 2014). Thus the interaction between osteocalcin and hormones of reproduction does not allow feedback regulation.

Finally, male fertility appears to be controlled by dual mechanisms, one of which (via osteocalcin) is independent of the hypothalamo-pituitary axis. Osteocalcin deficiency could be hypothetically considered a new pathogenetic factor responsible for primary testicular failure in men. On the other hand, El-Kamsoushi et al. (2016) did not find any correlation between serum un-osteocalcin, sperm concentration, morphology and motility or between un-osteocalcin and serum testosterone or LH levels. Therefore, the hypothesis that serum osteocalcin has any predictive value in male reproduction remains to be further investigated.

Here it is appropriate to mention the role, which another hormone involved in bone remodeling, $1,25(\mathrm{OH})_{2}$ vitamin $\mathrm{D}$, plays in male reproduction. Its receptors, as well as metabolizing enzyme CYP24A1 are expressed in the gonads and spermatozoa and modulate sex steroid synthesis, similarly to semen quality. That it is why vitamin D supplementation is successfully used in assisted reproduction (Boisen et al. 2017). Major studies in this field are needed.

Theoretically, bone marrow adipokines also have a systemic endocrine effect, which are known to negatively influence the cardiometabolic status (Sulston and Cawthorn 2016). However, the findings are mostly based on experimental results.

\section{Concluding remarks}

The skeleton shows unconventional meaning in the physiology and pathophysiology of the human organism, not only as target tissue for a number of systemic hormones, but also as an endocrine tissue targeting a number of extraskeletal systems. Osteocytes, which create up to $95 \%$ of all bone cells, play a fundamental role in these processes. Osteocytes function as mechano-sensors, which, via sclerostin, modulate bone remodeling. Besides sclerostin, osteocytes express phosphatonins regulating above all the phosphate metabolism. The osteocytes are effectively modulated by vitamin D. VDR deficient animals have been shown to increase osteocyte apoptosis and have impaired canalicular connectivity (Rolvien et al. 2017).

Further endocrine cells of the skeleton involved in bone remodeling are osteoblasts, which express osteocalcin. Besides phosphate homeostasis, osteocalcin modulates the energy metabolism and male reproduction (Bonewald 2011). Thus, this molecule shows some promise in the treatment of diabetes, insulin resistance and obesity (Ferron and Lacombe 2014). Moreover, a correlation study in healthy older adults showed that plasma osteocalcin levels were positively associated with global cognitive performance in healthy women (Bradburn et al. 2016). Interestingly, a recent, relatively extensive study showed an association between high blood osteocalcin levels and low serum hemoglobin in elderly men (Lewerin et al. 2016). New knowledge of the interactions between bone and extraskeletal systems may signify a new approach, not only in the treatment of osteoporosis.

\section{Conflict of Interest}

There is no conflict of interest.

\section{Acknowledgements}

This work was supported by the project (Ministry of Health, Czech Republic) for conceptual development of research organization $00023761 \quad$ (Institute of Endocrinology, Prague, Czech Republic).

\section{References}

ANDERSON PH, TURNER AG, MORRIS HA: Vitamin D actions to regulate calcium and skeletal homeostasis. Clin Biochem 45: 880-886, 2012. 
APPELMAN-DIJKSTRA NM, PAPAPOULOS SE: Sclerostin inhibition in the management of osteoporosis. Calcif Tissue Int 98: 370-380, 2016.

BOISEN IM, BØLLEHUUS HANSEN L, MORTENSEN LJ, LANSKE B, JUUL A, BLOMBERG JENSEN M: Possible influence of vitamin D on male reproduction. J Steroid Biochem Mol Biol 173: 215-222, 2017.

BONEWALD LF: The amazing osteocyte. J Bone Miner Res 26: 229-238, 2011.

BOUCHER-BERRY C, SPEISER PW, CAREY DE, SHELOV SP, ACCACHA S, FENNOY I, RAPAPORT R, ESPINAL Y, ROSENBAUM M: Vitamin D, osteocalcin, and risk for adiposity as comorbidities in middle school children. J Bone Miner Res 27: 283-293, 2012.

BRADBURN S, MCPHEE JS, BAGLEY L, SIPILA S, STENROTH L, NARICI MV, PÄÄSUKE M, GAPEYEVA H, OSBORNE G, SASSANO L, MESKERS CG, MAIER AB, HOGREL JY, BARNOUIN Y, HITLERBROWNE G, MURGATROYD C: Association between osteocalcin and cognitive performance in healthy older adults. Age Ageing 45: 844-849, 2016.

BRUZZESE A, LACQUANITI A, CERNARO V, RICCARDI CA, LODDO S, ROMEO A, MONTALTO G, CONSTANTINO G, TORRE F, PETTINATO G, SALAMONE I, ALOISI C, SANTORO D, BUEMI M: Sclerostin levels in uremic patients: a link between bone and vascular disease. Ren Fail 38: 759-764, 2016.

CAPULLI M, PAONE R, RUCCI N: Osteoblast and osteocyte: games without frontiers. Arch Biochem Biophys 561: 3-12, 2014.

CAPPARIELLO A, PONZETTI M, RUCCI N: The „soft“ side of the bone: unveiling its endocrine functions. Horm Mol Biol Clin Investig 28: 5-20, 2016.

CAVALLI L, MAZZOTTA C, BRANDI ML: Phosphatonins: physiological role and pathological changes. Clin Cases Miner Bone Metab 9: 9-12, 2016.

CHAPURLAT RD, CONFAVREUX CB: Novel biological markers of bone: from bone metabolism to bone physiology. Rheumatology (Oxford) 55: 1714-1725, 2016.

COLLINGE C: An injectable BMP cocktail for fracture-healing--a study that others have only imagine: commentary on the article by Thomas Lyon, MD, et al. „Efficacy and safety of recombinant human bone morphogenetic protein-2/calcium phosphate matrix for closed tibial diaphyseal fracture. a double-blind, randomized, controlled phase-II/III trial““. J Bone Joint Surg Am 95: e1891-e1892, 2013.

CURTIS KJ, COUGHLIN TR, MASON DE, BOERCKEL JD, NIEBUR GL: Bone marrow mechanotransduction in porcine explants alters kinase activation and enhances trabecular bone formation in the absence of osteocyte signaling. Bone 107: 78-87, 2017.

DALLAS SL, PRIDEAUX M, BONEWALD LF: The osteocyte: an endocrine cell and more. Endocr Rev 34: 658-690, 2013.

DELGADO-CALLE J, BELLIDO T: Osteocytes and skeletal pathophysiology. Curr Mol Biol Rep 1: 157-167, 2015.

DICEMBRINI I, MANNUCCI E, ROTELLA CM: Bone: incretin hormones perceiver or receiver? Exp Diabetes Res $\mathbf{5}$ : 519784, 2012.

DRAKE MT, KHOSLA S: Hormonal and systemic regulation of sclerostin. Bone 96: 8-17, 2017.

DUMIC-CULE I, DRACA N, LUETIC AT, JEZEK D, ROGIC D, GRGUREVIC L, VOKICEVIC S: TSH prevents bone resorption and with calcitriol synergistically stimulates bone formation in rats with low levels of calciotropic hormones. Horm Metab Res 46: 305-312, 2014.

EL-KAMSHOUSHI AAM, HASSAN EM, HASSAN PS: Evaluation of serum level of osteocalcin hormone in male infertility. Andrologia 49: 2017. doi: 10.1111/and.12755.

ERBEN RG: Update on FGF23 and Klotho signaling. Mol Cell Endocrinol 432: 56-65, 2016.

FAN Y, BI R, DENSMORE MJ, SATO T, KOBAYASHI T, YUAN Q, ZHOU X, ERBEN RG, LANSKE B: Parathyroid hormone 1 receptor is essential to induce FGF23 production and maintain systemic mineral homeostasis. FASEB J 30: 428-440, 2016.

FERRON M, LACOMBE J: Regulation of energy metabolism by the skeleton: Osteocalcin and beyond. Arch Biochem Biophys 156: 137-146, 2014.

FERRON M, LACOMBE J, GERMAIN A, OURY F, KARSENTY G: GGCX and VKORC1 inhibit osteocalcin endocrine functions. $J$ Cell Biol 208: 761-776, 2015. 
HENSEL N, SCHÖN A, KONEN T, LÜBBEN V, FÖRTHMANN B, BARON O, GROTHE C, LEIFHEIT-NESTLER M, CLAUS P, HAFFNER D: Fibroblast growth factor 23 signaling in hippocampal cell: impact on neuronal morphology and synaptic density. J Neurochem 137: 756-769, 2016.

HOLDSWORTH G, GREENSLADE K, JOSE J, STENCEL Z, KIRBY H, MOORE A, KE HZ, ROBINSON MK: Dampening of the bone formation response following repeat dosing with sclerostin antibody in mice is associated with up-regulation of Wnt antagonists. Bone 107: 93-103, 2017.

KALEM MN, KALEM Z, AKGUN N, BAKIRARAR B: The relationship between postmenopausal women's sclerostin levels and their bone density, age, body mass index, hormonal status, and smoking and consumption of coffee and dairy products. Arch Gynecol Obstet 295: 785-793, 2017.

KALUDJEROVIC J, KOMABA H, SATO T, ERBEN RG, BARON R, OLAUSON H, LARSSON TE, LANSKE B: Klotho expression in long bones regulates FGF23 production during renal failure. FASEB $J$ 31: 2050-2064, 2017.

KANDA E, YOSHIDA M, SASAKI S: Applicability of fibroblast growth factor for evaluation of risk of vertebral fracure and chronic kidney disease-mineral bone disease in elderly chronic kidney disease patients. $B M C$ Nephrol 13: 122, 2012.

KARSENTY G: The mutual dependence between bone and gonads. J Endocrinol 213: 107-114, 2012.

KARSENTY G, OURY F: Regulation of male fertility by the bone-derived hormone osteocalcin. Mol Cell Endocrinol 382: 521-526, 2014.

KITAMURA K, TAKAHIRA K, INARI M, SATOH Y, HAYAKAWA K, TABUCHI Y, OGAI K, NISHIUCHI T, KONDO T, MIKUNI-TAKAGAKII Y, CHEN W, HATTORI A, SUZUKI N: Zebrafish scales respond differently to in vitro dynamic and static acceleration: analysis of interaction between osteoblasts and osteoclasts. Comp Biochem Physiol Mol Integr Physiol 166: 74-80, 2013.

KONDO A, TOKUDA H, MATSUSHIMA-NISHIWAKI R, KUROYANAGI G, YAMAMOTO N, MIZUTANI J, KOUAWA O, OTSUKA T: Rho-kinase limits BMD-4-stimulated osteocalcin synthesis in osteoblasts: regulation of the p38 MAP kinase pathway. Life Sci 96: 18-25, 2014.

KUMAR A, SHEKHAR S, DHOLE B: Thyroid and male reproduction. Indian J Endocrinol Metab 18: 23-31, 2014.

KUROSU H, KURO-O M: Endocrine fibroblast growth factors as regulators of metabolic homeostasis. Biofactors $\mathbf{3 5}$ : $52-60,2009$.

KURO-O M: The FGF23 and Klotho system beyond mineral metabolism. Clin Exp Nephrol 21 (Suppl 1): S64-S69, 2017.

LAURENT M, ANTONIO L, SINNESAEL M, DUBIOS V, GIELEN E, CLASSENS F, VANDERSCHUEREN D: Androgens and estrogens in skeletal sexual dimorphism. Asian J Androl 16: 213-222, 2014.

LEVINGER I, LIN X, ZHANG X, BRENNAN-SPERANZA TC, VOLPATO B, HAYES A, JERUMS G, SEEMAN E, MCCONELL G: The effects of muscle contraction and recombinant osteocalcin on insulin sensitivity ex vivo. Osteoporos Int 27: 653-663, 2016.

LEWERIN C, JOHANSSON H, KARLSSON MK, LORENTZON M, LERNER UH KINDBLOM JM, OHLSSON C, SMITH U, MELLSTRÖM D: High plasma osteocalcin is associated with low blood hemoglobin in elderly men: the MrOS Sweden Study. J Intern Med 280: 398-406, 2016.

MACE ML, GRAVESEN F, NORDHOLM A, HOFMAN-BANG J, SECHER T, OLGAARD K, LEWIN E: Kidney fibroblast growth factor 23 does not contribute to elevation of its circulating levels in uremia. Kidney Int $\mathbf{9 2}$ : 165-178, 2017.

MATSUI S, YASUJ T, KASAI K, KEYAMA K, KATO T, UEMURA H, KUWAHARA A, MATSUZAKI T, IRAHARA M: Increase in circulating sclerostin at the early stage of menopausal transition in Japanese women. Maturitas 83: 72-77, 2016.

MCCLUNG MR: Clinical utility of anti-sclerostin antibodies. Bone 96: 3-7, 2017.

MERA P, LAUE K, FERRON M, CONFAVREUX C, WEI J, GALA-DÍEZ M, LACAMPAGNE A, MITCHELL SJ, MATTISON JA, CHEN Y, BACCHETTA J, SZULC P, KITSIS RN, DE CABO R, FRIEDMAN RA, TORSITANO C, MCGRAW TE, PUCHOWICZ M, KURLAND I, KARSENTY G: Osteocalcin signaling in myofibers is necessary and sufficient for optimum adaptation to exercise. Cell Metab 23: 1078-1092, 2016. 
MÖDDER UI, HOEY KA, AMIN S, MCCREADY LK, ACHENBACH SJ, RIGGS BL, MELTON LJ 3RD, KHOSLA S: Relation of age, gender, and bone mass to circulating sclerostin levels in women and men. J Bone Miner Res 26: 373-379, 2011.

IZOKAMI A, KAWAKUBO-YASUKOCHI T, IRATA M: Osteocalcin and its endocrine functions. Biochem Pharmacol 132: 1-8, 2017.

MIZOKAMI A, YASUTAKE Y, HIGASHI S, KAWAKUBO-YASUKOCHI T, CHISHAKI S, TAKAHASHI I, TAKEUCHI H, HIRATA M: Oral administration of osteocalcin improves glucose utilization by stimulating glucagon-like peptide-1 secretion. Bone 69: 68-79, 2014.

NAKAHAMA K: Cellular communications in bone homeostasis and repair. Cell Mol Life Sci 67: 4001-4009, 2010.

NEVE A, CORRADO A, CANTATORE FP: Osteocytes: central conductors of bone biology in normal and pathological conditions. Acta Physiol (Oxf) 204: 317-330, 2012.

OURY F: A crosstalk between bone and gonads. Ann N Y Acad Sci 1260: 1-7, 2012.

OKUYAMA MW, SHIMOZURU M, YANAGAWA Y, TSUBOTA T: Changes in the immunolocalization of steroidogenic enzymes and the androgen receptor in raccoon (Procyon lotor) testes in association with the season and spermatogenesis. $J$ Reprod Dev 60: 155-161, 2014.

OLAUSON H, MENCKE R, HILLEBRANDS JL, LARSSON TE: Tissue expression and source of circulating aKlotho. Bone 100: 19-35, 2017.

OURY F, FERRON M, HUIZHEN W, CONFAVREUX C, XU L, LACOMBE J, SRINIVAS P, CHAMOUNI A, LUGANI F, LEJEUNE H, KUMAR TR, PLOTTON I, KARSENTY G: Osteocalcin regulates murine and human fertility through a pancreas-bone-testis axis. J Clin Invest 123: 2421-2433, 2013.

OURY F, SUMARA G, SUMARA O, FERRONI M, CHANG H, SMITH CE, HERMO L, SUAREZ S, ROTH BL, DUCY P, KARSENTY G: Endocrine regulation of male fertility by the skeleton. Cell 144: 796-809, 2011.

PI M, QUARLES LD: Novel bone endocrine network integrating mineral and energy metabolism. Curr Osteoporos Rep 11: 391-399, 2013.

QUARLES LD: Skeletal secretion of FGF-23 regulates phosphate and vitamin D metabolism. Nat Rev Endocrinol 8: 276-286, 2012.

QUINTERO-PLATT G, GONZÁLEZ-REIMERS E, RODRÍGUEZ-GASPAR M, MARTÍN-GONZÁLEZ C, PÉREZHERNÁNDEZ O, ROMERO-ACEVEDO L, ESPELOSÍN-ORTEGA E, DE LA VEGA-PRIETO MJ, SANTOLARIA-FERNÁNDEZ F: Alpha Klotho and fibroblast growth factor-23 among alcoholics. Alcohol Alcohol 52: 542-549, 2017.

QAW FS, MAKIN HL, JONES G: Metabolism of 25-hydroxydihydrotachysterol3 in bone cells in vitro. Steroids 57: 236-243, 1992.

REPP F, KOLLMANNSBERGER P, ROSCHGER A, KERSCHNITZKI M, BERZLANOVICH A, GRUBER GM, ROSCHGER P, WAGERMAIER W, WEINKAMER R: Spatial heterogeneity in the canalicular density of the osteocyte network in human osteons. Bone Rep 6: 101-108, 2017.

RHEE Y, BIVI N, FARROW E, LEZCANO V, PLOTKIN LI, WHITE KE, BELLIDO T: Parathyroid hormone receptor signaling in osteocytes increases the expression of fibroblast growth factor- 23 in vitro and in vivo. Bone 49: 636-643, 2011.

ROCHERFORT GY, BENHAMOU CL: Osteocytes are not only mechanoreceptive cells. Int J Numer Metod Biomed Eng 29: 1982-1988, 2013.

ROLVIEN T, KRAUSE M, JESCHKE A, YORGAN T, PÜSCHEL K, SCHINKE T, BUSSE B, DEMAY MB, AMLING M: Vitamin D regulates osteocyte survival and perilacunar remodeling in human and murine bone. Bone 103: 78-87, 2017.

SAPIR-KOREN R, LIVSHITS G: Bone mineralization is regulated by signaling cross talk between molecular factors of local and systemic origin: the role of fibroblast growth factor 23. Biofactors 40: 555-568, 2014.

SATO S, TAKEDA S: The regulation of various organs by osteoblasts. Clin Calcium 26: 721-727, 2016.

SHORFF R: Phosphate is a vascular toxin. Pediatr Nephrol 28: 583-593, 2013.

SIMON D, DERER A, ANDES FT, LEZUO P, BOZEC A, SCHETT G, HERRMANN M, HARRE U: Galectin-3 as a novel regulator of osteoblast-osteoclast interaction and bone homeostasis. Bone 105: 35-41, 2017. 
SPATZ JM, WEIN MN, GOOI JH, QU Y, GARR JL, LIU S, BARRY KJ, UDA Y, LAI F, DEDIC C, BALCELLSCAMPS M, KRONENBERG HM, BABIJ P, PAJEVIC PD: The Wnt inhibitor sclerostin is up-regulated by mechanical unloading in osteocytes in vitro. J Biol Chem 290: 16744-16758, 2015.

STOUFFS K, SENECA S, LISSENS W: Genetic cause of male infertility. Ann Endocrinol (Paris) 75: 109-111, 2014.

SUEN PK, ZHU TY, CHOW DH, JUANY L, ZHENG LZ, QUIN L: Sclerostin antibody treatment increases bone formation, bone mass, and bone strength of intact bones in adult male rats. Sci Rep 5: 15632, 2015.

SULSTON RJ, CAWTHORN WP: Bone marrow adipose tissue as an endocrine organ: close to the bone? Horm Mol Biol Clin Invest 28: 21-38, 2016.

TORRES PU, PRIÉ D, BECK L, DE BRAUWERE D, LEROY C, FRIEDLANDER G: Klotho gene, phosphocalcic metabolism, and survival in dialysis. J Ren Nutr 19: 50-56, 2009.

TURNER CH, WARDEN SJ, BELLIDO T, PLOTKIN LI, KUMAR N, JASIUK I, DANZIG J, ROBLING AG: Mechanobiology of the skeleton. Sci Signal 2: pt3, 2009. doi 10.1126/scisignal 268pt3.

TURNER AG, HANRATH MA, MORRIS HA, ATKINS GJ, ANDERSON PH: The local production of 1,25(OH) promotes osteoblast and osteocyte maturation. J Steroid Biochem Mol Biol 144: 114-118, 2014.

VERVLOET MG, ADEMA AY, LARSSON TE, MASSY ZA: The role of Klotho on vascular calcification and endothelial function in chronic kidney disease. Semin Nephrol 34: 578-585, 2014.

WEILER HA, LOWE J, KRAHN J, LESLIE WD: Osteocalcin and vitamin D status are inversely associated with homeostatic model assessment of insulin resistance in Canadian Aboriginal and white women: the First Nations Bone Health Study. J Nutr Biochem 24: 412-428, 2013.

YAVROPOULOU MP, YOVOS JG: Incretins and bone: evolving concepts in nutrient-dependent regulation of bone turnover. Hormones (Athens) 12: 214-223, 2013.

ZHANG M, XUAN S, BOUXSEIN M, VON STECHOW D, AKENO N, FAUGERE M C, MALLUCHE H, ZHAO G, ROSEN CJ, EFSTRATIADIS A, CLEMENS TL: Osteoblast-specific knockout of the insulin-like growth factor (IGF) receptor gene reveals an essentials role of IGF signaling in bone matrix mineralization. $J$ Biol Chem 277: 44005-44012, 2002.

ZAGRODNA A, JÓŹKÓW P, MEDRAŚ M, MAJDA M, SLOWIŃSKA-LISOWSKA M: Sclerostin as a novel marker of bone turnover in athletes. Biol Sport 33: 83-87, 2016.

ZOCH ML, CLEMENS TL, RIDDLE RC: New insights into the biology of osteocalcin. Bone 82: 42-49, 2016.

ZOFKOVA I, HILL M: Biochemical markers of bone remodeling correlate negatively with circulating TSH in postmenopausal women. Endocr Regul 42: 121-127, 2008.

ZOFKOVA I: Bone tissue as a systemic endocrine regulator. Physiol Res 64: 439-445, 2015. 